\title{
Asymptomatic intestinal helminth co-infection among pulmonary tuberculosis patients in urban Surabaya: a preliminary study
}

Rifat Nurwita Kusumaningtyas ${ }^{1}$, Indah Setyawati Tantular ${ }^{2}$, Deby Kusumaningrum $^{3}$, Rina K Kusumaratna ${ }^{4}$

\begin{abstract}
\section{BACKGROUND}

Pulmonary tuberculosis (TB) is a leading cause of morbidity and mortality, and East Java province is the second largest contributor of co-infection in Indonesia. Asymptomatic helminth infection among pulmonary tuberculosis patients causes another public health problem. Few data relate to helminth infection based on clinical and immunological outcomes of pulmonary TB in highly endemic areas.
\end{abstract}

\section{METHODS}

This study was designed as a preliminary study and aimed to determine helminth co-infection among TB patients with a macroscopic assessment. This cross-sectional study was conducted in June-August 2017.

\section{RESULTS}

Among 16 treated active TB patients from TB cohort data of Tanakali Kedinding health center found that $56 \%$ were stool smear-positive for Trichuris trichiura eggs, but had no clinical symptoms.

\section{CONCLUSION}

Whether or not the helminth infection may have an impact on the diagnosis and treatment of active TB remains to be further investigated. Co-infection could be inhibited by the host immune response and improve the prognosis of TB treatment.

Keywords: co-infection, helminthiasis, tuberculosis, urban area

\author{
${ }^{1}$ Lulusan Program Studi Profesi \\ Pendidikan Dokter, Fakultas \\ Kedokteran Universitas Airlangga, \\ Surabaya, Indonesia \\ 2 Departemen Parasitologi, Fakultas \\ Kedokteran Universitas Airlangga, \\ Surabaya, Indonesia \\ ${ }^{3}$ Departemen Mikrobiologi, \\ Fakultas Kedokteran Universitas \\ Airlangga, Surabaya, Indonesia \\ ${ }^{4}$ Departemen Ilmu Kesehatan \\ Masyarakat, Fakultas Kedokteran \\ Universitas Trisakti, Indonesia
}

\section{Korespondensi: \\ Rifat Nurwita Kusumaningtyas Program Studi Profesi Pendidikan Dokter, Fakultas Kedokteran Universitas Airlangga, Surabaya, Indonesia Email: rkusumaningtyas@gmail. com}

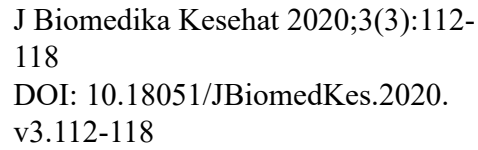

Artikel akses terbuka (open access) ini didistribusikan di bawah lisensi Creative Commons Attribution 4.0 International (CC-BY 4.0) 


\section{ABSTRAK \\ Ko-infeksi asimptomatik helminthiasis pada pasien tuberkulosis paru di kota Surabaya: studi pendahuluan}

\section{LATAR BELAKANG}

Penyakit tuberculosis paru (TB) hingga saat ini masih menjadi penyebab utama tingginya angka morbiditas dan mortalitas, dan propinsi Jawa Timur termasuk penyumbang penderita kedua terbanyak di Indonesia. Hanya sedikit data informasi diketahui terkait infeksi kecacingan yang terjadi pada penderita TB baik secara klinis dan imunologi pada daerah endemis.

\section{METODE}

Studi ini di desain sebagai studi awal dan bertujuan untuk menilai ko-infeksi kecacingan diantara penderita TB. Studi potong-lintang ini dilakukan pada bulan Juni-Agustus 2017.

\section{HASIL}

Enam belas penderita aktif TB berdasarkan data kohort tuberkulosis Puskesmas Tanakali Kedinding, didapatkan 56\%-nya positif kecacingan dengan ditemukannya telur Trichuris trichiura.

\section{KESIMPULAN}

Walaupun efek dari infeksi kecacingan tidak berdampak terhadap diagnosis dan pengobatan tuberkulosis, akan tetapi sebaiknya penderita yang terdeteksi sebagai tuberkulosis aktif, dilakukan skrining kecacingan terlebih dahulu. Ko-infeksi dapat dihampat oleh respon imun penderita dan meningkatkan prognosis pengobatan tuberkulosis.

Kata kunci: ko-infeksi, helminthiasis, tuberkulosis, perkotaan

\section{INTRODUCTION}

Pulmonary tuberculosis (TB) is an infectious disease caused by Mycobacterium tuberculosis that has high morbidity and mortality rates. The infection occurs through the inhalation of droplets containing viable bacteria of persons infected with Mycobacterium tuberculosis. (1) Radiographs show that Mycobacterium tuberculosis has a predilection for the apex of the lungs but may also cause infections in other organs, which is called extra-pulmonary TB. According to National Health Report data 2016, tuberculosis is still one of the leading causes of high morbidity among all infectious diseases at the health centers and Indonesia was in the third rank among TB burden countries. ${ }^{(2)}$

Due to our geographic conditions, especially the population concentrations living in urban and rural areas and engaged in various economic activities, the distributions of some Neglected Tropical Diseases (NTD) are overlapping. In developing countries, people living in slum and squatter areas are usually easily affected with tuberculosis and intestinal helminth infection, especially co-infection with soil-transmitted helminths. It is well-known that intestinal parasitic infections are also one of the neglected tropical infections and one of the most common infections in the world. ${ }^{(3)}$ The occurrence of co-infection of TB and intestinal helminthiasis has become one of the major public health problems in Indonesia. However, there are no current data regarding the co-infection of helminthiasis among TB patients. The majority of the data in Indonesia only refer to single diseases, such as the prevalence rate of pulmonary tuberculosis or the prevalence rate of helminthiasis in Indonesia. Only one study conducted in Bandung, West Java with immunological assessment found $30.5 \%$ coinfection of helminths in TB patients compared to the $57.8 \%$ found in Brazil. ${ }^{(4,5)}$

The present study was designed as a preliminary study and aimed to determine helminthiasis co-infection among TB patients with macroscopic assessment, a conventional technic that could be used in primary health care. The study also aimed to explore and generate information on comprehensive TB treatment and eradication, especially in endemic areas.

\section{METHODS}

The study was conducted from June to August 2017 in the catchment area of Tanakali Kedinding Health Centre, Surabaya, East Java, an urban area located next to the Suramadu bridge of Surabaya city. The area is known as an urban slum and squatter area, where the incidence of pulmonary tuberculosis (TB) is the highest of the other areas.

A cross-sectional study was conducted among all subjects who had already been diagnosed with clinical symptoms as a TB patient and had 
acid-fast bacilli (BTA) positive sputum smear microscopy at the health center as part of the standard TB treatment program. All of the subjects were registered as an active patient in the TB cohort database and received TB treatment. The study subjects were taken by purposive sampling so that 16 subjects TB active were enrolled in this study.

The subjects' characteristics and risk factor information such as medical history, environmental sanitation, and patient's behavior were collected through interviews using a structured questionnaire, and by observation and home visits. To explore helminth co-infection among pulmonary tuberculosis patients, the study used stool specimens and examined them for the presence of parasites by the microscopic direct smear method. Stool samples were collected from all subjects and processed for the examination of parasites at the Parasitology Laboratory, Faculty of Medicine, Airlangga University. An applicator/ toothpick was used to mix one small drop of faces with water on a clean glass slide. A thin smear was made and covered with a coverslip. The area under the coverslip was examined using 10x and 40x objectives.

Data processing was performed by simple descriptive analysis to explain the characteristics, risk factors, and helminth co-infection among TB patients. The study was approved by the Ethics Review Board of the Faculty of Medicine, Airlangga University (No.3853/UN3.1.1/ PPd.10/2016), and permission to conduct the study in the community was obtained from the Head of Tanakali Kedinding Health Centre, Surabaya. Informed verbal consent was obtained from each study subject and any information related to the study was kept confidential.

\section{RESULTS}

The study involved 35 subjects from the total number listed in the 2016 TB cohort database at Tanakali Kedinding health center. The subjects were selected by purposive sampling based on the inclusion criterion of residing within an $8 \mathrm{~km}$ radius around the health center. Only 17 subjects could be visited based on their home address and 16 returned the pot with stool samples to be examined, while one subject could not because of a defecation problem.
Table 1. Laboratory results of TB patients' stool direct smear of Puskesmas Tanakali Kedinding Surabaya

\begin{tabular}{lcc}
\hline \multicolumn{1}{c}{ Parameter } & n (\%) \\
\hline $\begin{array}{l}\text { Stool - direct } \\
\text { smear : }\end{array}$ & & \\
$\begin{array}{l}\text { Helminth eggs } \\
\text { detected }\end{array}$ & Positive & $9(56.25)$ \\
& Negative & $7(43.75)$ \\
Type of parasite & $\begin{array}{l}\text { Trichuris } \\
\text { trichiura }\end{array}$ & + \\
\hline
\end{tabular}

Based on the stool direct smear results 9 out of 16 subjects $(56.25 \%)$ who suffered from pulmonary tuberculosis were positively coinfected with soil-transmitted helminths (STH), which was Trichuris trichiura. The internal factors among subjects were under 60 years, male and only $44 \%$ has National Health Insurance (JKN).

Table 2. Characteristics and clinical history of TB patients Tanakali Kedinding Surabaya

\begin{tabular}{lll}
\hline \multicolumn{2}{c}{ Variabels } & n (\%) \\
\hline \multirow{2}{*}{ Age } & $<60 \mathrm{yr}$ & $12(75)$ \\
& $\geq 60 \mathrm{yr}$ & $4(25)$ \\
Sex & Male & $9(56)$ \\
& Female & $7(44)$ \\
Health insurance & JKN & $7(44)$ \\
& none & $9(56)$ \\
BCG immunization & Yes & $7(44)$ \\
& No & $9(56)$ \\
TB in family & Yes & $4(25)$ \\
& No & $12(75)$ \\
BTA smear - 1 & Positive & $11(68.8)$ \\
& Negative & $5(31.2)$ \\
Length of treatment & $2-6 \mathrm{mo}$ & $3(18.8)$ \\
& $<2 \mathrm{mo}$ & $6(37.6)$ \\
BMI & recurrent & $7(43.6)$ \\
& $<18.5 \mathrm{~kg} / \mathrm{m}^{2}$ & $7(44)$ \\
& $18.5-22.9 \mathrm{~kg} / \mathrm{m}^{2}$ & $9(56)$ \\
\hline
\end{tabular}

Fifty sixth percent $(56 \%)$ of subjects got BCG while infancy, only $25 \%$ has tuberculosis family-related, and $68.8 \%$ were positive in the first smear, $43.6 \%$ among subjects were recurrent TB treatment and normal nutritional status.

Table 3. Environmental and practices factors

\begin{tabular}{lll}
\hline \multicolumn{2}{c}{ Variabels } & n (\%) \\
\hline \multirow{2}{*}{ Environmental score } & Good & $6(37.5)$ \\
& Poor & $10(62.5)$ \\
\multirow{2}{*}{ Health practices } & Good & $14(87.5)$ \\
& Poor & $2(12.5)$ \\
\hline
\end{tabular}


Based on the environmental score which was house observation and sanitation, $62.5 \%$ was poor, however for health practices, $87.5 \%$ has a good scoring.

\section{DISCUSSION}

Subjects with tuberculosis were positively infected with Trichuris trichiura, it is also known that infections caused by intestinal parasites do not cause clinical symptoms, thus why the active pulmonary TB subjects never complain about the infestation. The results of this study were similar to those of previous studies on helminth co-infection that have been conducted by in Indonesia, Ethiopia, and Africa, although there are differences in the number of subjects and incidence rate. ${ }^{(4,6-8)}$ This study supports the statements that have been made by their previous studies, although this preliminary study did not determine the causes and screen immunology indicators.

Based on the internal factors that have been explored, the majority (77\%) of TB coinfection subjects were less than 60 years old (range 25 to 56 years) and consisted of an equal number of both genders. Most of the subjects did not have Indonesian National Health Insurance (JKN) card, thus received continued TB treatment only by showing their national identity card (KTP), which means the treatment was covered under Provincial Health Insurance (Jamkesda). To get the appropriate treatment of tuberculosis Directly Observes Treatment Short Course (TB DOTS) program, there have to be no services care access barrier at the health center. Of the total number of TB treatment subjects in Tanakali Kedinding, $44 \%$ were on TB recurrent and new cases of TB phase 1 and phase 2 of DOTS program treatment, and $25 \%$ cases of intestinal helminths co-infection were found among the recurrent TB treatment subjects. From discussion with them, the patients already knew that all treatment under the DOTS program was covered by the government, which means that the patients do not need to pay for the treatment. However, they should comply with the programmed treatment and take the package of medicine as prescribed by the doctor, and routine control to get continuing medicine and follow-up their treatment compliance by periodical screen of sputum BTA as an indicator of progress therapy. Despite of this, many of the TB patients, in general, tend to stop treatment prematurely, which is one risk factor become multi-drug resistance of tuberculosis (MDR-TB) and further some cases become develop of extensively drug-resistance tuberculosis (XDR-TB)..$^{(1,2)}$

Based on the clinical history of the coinfection TB patients, more than half of the subjects (56.2\%) never received BCG immunization in childhood. In a study conducted by Elias et al., it is stated that there is the possibility of helminth infection among TB patients due to disruption of the immune response in antigen recognition of Mycobacterium tuberculosis due to lack of previous exposure to mycobacteria ${ }^{(9,10)}$ A study by Elias et al. also reported that administration of anthelmintics among TB patients who had been vaccinated with $B C G$, had increases in IFNgamma and IL-12, compared to subjects not given the anthelmintics. ${ }^{(11)}$ However, patients who were not given anthelmintics had increased levels of TGF-beta. ${ }^{(12)}$ One of TGF-beta functions as a suppressor immune mediator that might block the inflammation process. Usually, helminthiasis infection was chronic and increased the level of TGF-beta expression. This indicates one of the possible causes of the high rate of TB, especially in tropical regions, i.e. a decrease in immunogenicity of the BCG vaccine. ${ }^{(13)}$ Thus it could be stated that patients who are not vaccinated become more vulnerable. However, the exact mechanism is still unknown, even from the theory we learned that helminth infection-induced $\mathrm{T}$ helper-2 and T-regulator, and the responses may contribute to depressed Mycobacterium tuberculosis specifically T-cell response. ${ }^{(14)}$ Apart from BCG immunization issues, the result found that apparently, most respondents were in the initial phase of TB treatment ( 2 months) or under treatment for recurrent tuberculosis. The severity of co-infection depends on the intensity of helminth infestation in the subject's body because the infestation is related to immune response. ${ }^{(4,15)}$ In the current study, we could not determine the intensity of infestation or severity of infection, due to used only stool direct smears as a screening tool for helminthiasis.

Among those who get treatment as tuberculosis patients, $25 \%$ of co-infection has a history of tuberculosis within the family. At the first sputum smear examination, most of the 
subjects' sputum result was positive $(68.8 \%)$, and at the second examination after phase I of treatment, the BTA sputum smear result became negative $(68.8 \%)$, and the rest $(25 \%)$ was not yet checked at that time. The anthropometry that we have conducted is based on WHO definition. The results of nutritional status among the co-infection subjects and no co-infection of those who received treatment were underweight to normal. The current situation was supported by the theory that TB patients in the course of the disease to prevent weight loss and ultimately causes a decrease in the nutritional status. ${ }^{(16)}$ Low BMI would increase the severity of tuberculosis five times that of normal BMI. ${ }^{(17)}$ Similarly finding was also reported in Ethiopia. ${ }^{(18)}$ It can be concluded that in TB patients with poor nutritional status, in whom the nutrient adequacy requirements are not fulfilled; the immune system capacity to fight infection is reduced. Furthermore, this makes the TB subjects more prone to secondary infection, such as helminth infection, designated as co-infection.

Soil-transmitted intestinal helminth infestations such as ascariasis, trichuriasis, and hookworm disease, refer to intestinal worms infecting humans that are transmitted from contaminated soil through the fecal-oral route. As stated above, a parasite species found based on smears was Trichuris trichiura, similarly known as whipworms. The worm is a multi-cellular organism with a long, flat, or round body. The larvae of whipworms live in the large intestine of humans and can cause intestinal disease. The infection is caused by ingesting eggs when hands or fingers contaminated with soil with whipworms eggs are put in the mouth or by consuming vegetables or fruits that are not cooked or washed properly. Whipworm infection could be of light or heavy intensity; light infection usually gives no symptoms. Soil-transmitted helminths usually ocurs in warm and humid climates with poor hygiene and sanitation, such as in the current location where the environment is a slum and squatter area. Environmental factors such as crowded neighborhoods and houses without adequate ventilation and direct sunlight, lead to easy transmission and recurrent TB among the population. This environmental condition is the one found at Tanakali Kedinding sub-district, Surabaya city. People who live in this area under such conditions are at potential risk not only for helminths contamination but also for pulmonary tuberculosis. In such communities, both helminths and TB infection tend to cluster within households or families.

Referring to the TB patient cohort data in Puskesmas Tanakali Kedinding, we found that $56.25 \%$ were infected with soil-transmitted helminth co-infection. In general, the geographical distribution of STH is influenced by factors such as soil conditions, poor sanitation facilities, unhealthy sewage systems, lack of water resources, type of toilet, and socio-demography data. ${ }^{(14,19,20)}$ Our observed finding, most of the subjects already had a source of clean water and latrines in their houses, but the sewage (fecal waste) disposal system was not explored. It remains unclear whether the cause of co-infection was contamination with the

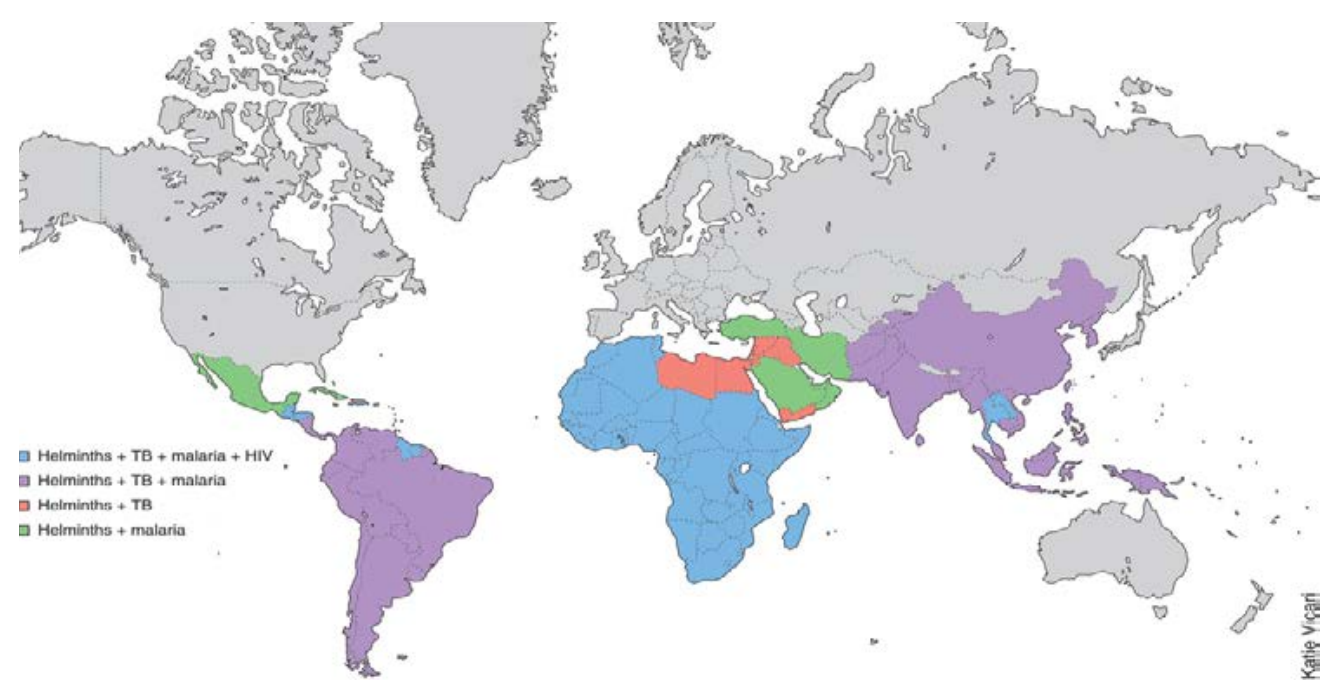

Figures 1. The geographical distribution of co-infection with helminths and tuberculosis $^{(21)}$ 
contaminated soil around the houses or due to unhealthy behavior, it means their behavior was not per clean and healthy living concept (Perilaku Hidup Sehat dan Bersih). Because TB co-infection with intestinal helminth is not only due to the environmental factors, but could also refer to unhealthy lifestyle among community members, such as not sufficiently implemented on water, sanitation, and hygiene (WASH) or non-hygienic food handling or not proper food handling and preparation at home or preference of buying food with not adequate sanitation from street vendors at their workplace due to practical habit.

From the below figure we could see the risk of infection and could be used as a reflection on national eradication programmed on tropic infection diseases.

Based on the simplified map made by Salgame according to WHO data showed the geographic distribution of tropical diseases, and Indonesia is shown as one of the countries that have a risk of three kinds of tropical diseases, helminths, tuberculosis, and malaria, or coinfection helminths and tuberculosis. Due to that reason and as stated by Anwar it should be conducted integrated control strategy, to lead reduction of STH at the community level. Further exploration is required to determine the risk factors for disease transmission of helminths among persons with tuberculosis in the endemic area. ${ }^{(14,21)}$

One limitation of this study was that it did not evaluate immunological parameters to show the immunological reactions against the intestinal parasitic infestation among the TB subjects.

\section{CONCLUSION}

The findings of this study support the assumption that there are positive cases of asymptomatic co-infection of intestinal helminth among pulmonary TB patients, for which we should be on the alert. Because tuberculosis and helminths infection could be overlap acquire infection among the population. The study recommend conducting screening and treatment for STH co-infection among TB patients.

\section{ACKNOWLEDGEMENTS}

The authors wish to thank the Head and staff of the TB program of Tanakali Kedinding
Health Center, Surabaya, DR. F. Sustini for her valuable information and support of access to the health center. We are grateful to ibu Evi Susanti Sinaga and dr. Richard Tjan for their assistance on manuscript review and valuable comments. We also thanks my friend Cynthia Butarbutar and TB cadres for their assistance and contribution while collecting information and stool samples.

\section{CONFLICT OF INTEREST}

All authors declare no conflicts of interest, and this is study was self-funded by the principal investigator.

\section{REFERENCES}

1. World Health Organization. Global tuberculosis report 2015 [Internet]. WHO. 2015 [cited 2018 Oct 3]. p. 1-145. Available from: https://apps.who.int/ iris/handle/10665/191102

2. Kementerian Kesehatan RI. Infodatin tuberkulosis [Internet]. Jakarta; 2016 [cited 2018 Oct 4]. Available from: http://www.depkes.go.id/ download.php?file=download/pusdatin/infodatin/ InfoDatin-2016-TB.pdf

3. Babu S, Nutman TB. Helminth-tuberculosis coinfection: an immunologic perspective. Trends Immunol [Internet]. 2016 Sep [cited 2018 Oct 10];37(9):597-607. Available from: http:// www.ncbi.nlm.nih.gov/pubmed/27501916 doi: 10.1016/j.it.2016.07.005

4. Astuti RDI, Sastramihardja HS, Masria S. Askariasis di daerah endemis rendah askariasis tidak meningkatkan kejadian tuberkulosis aktif. Glob Med Heal Commun [Internet]. 2016 Feb 1 [cited 2018 Oct 4];4(1):20. Available from: http:// ejournal.unisba.ac.id/index.php/gmhc/article/ view/1601doi: 10.29313/gmhc.v4i1.1601

5. Tristão-Sá R, Ribeiro-Rodrigues R, Johnson LT, et al. Intestinal nematodes and pulmonary tuberculosis. Rev Soc Bras Med Trop [Internet]. SBMT; 2002 Oct [cited 2018 Oct 4];35(5):5335. Available from: http://www.scielo.br/ scielo.php?script $=$ sci_arttext\&pid $=\mathrm{S} 0037$ $86822002000500020 \& \ln \bar{g}=$ en\&tlng=en doi: 10.1590/S0037-86822002000500020

6. Alemayehu M. Prevalence of smear positive tuberculosis, intestinal parasites and their coInfection among tuberculosis suspects in gondar university hospital and gondar poly clinic, North West Ethiopia. J Microb Biochem Technol [Internet]. 2014 [cited 2018 Oct 4];6(4):179-84. Available from: https://www.omicsonline.org/ open-access/prevalence-of-smear-positivetuberculosis-intestinal-parasites-and-theircoinfection-among-tuberculosis-suspects-ingondar-university-hospital-1948-5948.1000140. php?aid=25454 doi: 10.4172/1948-5948.1000140

7. Abate E, Belayneh M, Gelaw A, et al. The impact of asymptomatic helminth co-infection in patients with newly diagnosed tuberculosis in NorthWest Ethiopia. Schlievert PM, editor. PLoS One [Internet]. Public Library of Science; 2012 Aug 29 [cited 2018 Oct 4];7(8):e42901. Available from: http://dx.plos.org/10.1371/journal.pone.0042901 
doi: 10.1371/journal.pntd.0003994

8. Resende Co T, Hirsch CS, Toossi Z, et al. Intestinal helminth co-infection has a negative impact on both anti-mycobactrium tuberculosis immunity and clinical response to tuberculosis therapy. Clin Exp Immunol [Internet]. 2007;147(1):45-52. Available from: https://onlinelibrary.wiley.com/ doi/full/10.1111/j.1365-2249.2006.03247.x doi: 10.1111/j.1365-2249.2006.03247.x

9. Elias D, Akuffo H, Pawlowski A, et al. Schistosoma mansoni infection reduces the protective efficacy of BCG vaccination against virulent mycobacterium tuberculosis. Vaccine [Internet]. Elsevier; $2005 \mathrm{Feb}$ 3 [cited 2018 Oct 4];23(11):1326-34. Available from: https://www.sciencedirect.com/science/ article/pii/S0264410X04006954 doi: 10.1016/J. VACCINE.2004.09.038

10. Elias D, Mengistu G, Akuffo H, et al. Are intestinal helminths risk factors for developing active tuberculosis? Trop Med Int Heal [Internet]. 2006;11(4):551-8. Available from: https:// onlinelibrary.wiley.com/doi/full/10.1111/j.13653156.2006.01578.x doi: 10.1111/j.13653156.2006.01578.x

11. Elias D, Wolday D, Akuffo $\mathrm{H}$, et al. Effect of deworming on human $\mathrm{T}$ cell responses to mycobacterial antigens in helminth-exposed individuals before and after bacille CalmetteGuérin (BCG) vaccination. Clin Exp Immunol [Internet]. Wiley-Blackwell; 2001 Feb [cited 2018 Oct 4];123(2):219-25. Available from: http:// www.ncbi.nlm.nih.gov/pubmed/11207651 doi: 10.1046/J.1365-2249.2001.01446.X

12. Elias D, Britton S, Kassu A, et al. Chronic helminth infections may negatively influence immunity against tuberculosis and other diseases of public health importance. Expert Rev Anti Infect Ther [Internet]. 2007 Jun 10 [cited 2018 Oct 4];5(3):475-84. Available from: http:// www.ncbi.nlm.nih.gov/pubmed/17547511 doi: 10.1586/14787210.5.3.475

13. Rafi W, Ribeiro-Rodrigues R, Ellner JJ, et al. Coinfection-helminthes and tuberculosis. Curr Opin HIV AIDS [Internet]. Lippincott Williams and Wilkins; 2012 May [cited 2018 Oct 4];7(3):239-44. Available from: http://www.ncbi. nlm.nih.gov/pubmed/22411453 doi: 10.1097/ COH.0b013e3283524dc5

14. Anwar S. Impact of helminth infection on antimycobacterial immune responses in UK migrants [Internet]. University of London; 2017. Available from: http://researchonline.lshtm. ac.uk/4398419/1/2017 ITD PhD Anwar S.pdf doi: 10.17037/PUBS.04398419

15. Reina Ortiz M, Schreiber F, Benitez S, et al. Effects of chronic ascariasis and trichuriasis on cytokine production and gene expression in human blood: a cross-sectional study. Walson JL, editor. PLoS Negl Trop Dis [Internet]. 2011 Jun 7 [cited 2018 Oct 10];5(6):e1157. Available from: http://dx.plos. org/10.1371/journal.pntd.0001157 doi: 10.1371/ journal.pntd.0001157

16. Khan A, Sterling TR, Reves R, et al. Lack of weight gain and relapse risk in a large tuberculosis treatment trial. Am J Respir Crit Care Med [Internet]. American Thoracic Society; 2006 Aug 20 [cited 2018 Oct 4];174(3):344-8. Available from: http://www.atsjournals.org/doi/abs/10.1164/ rccm.200511-1834OC doi: 10.1164/rccm.200511$1834 \mathrm{OC}$
17. Tverdal A. Body mass index and incidence of tuberculosis. Eur J Respir Dis [Internet]. 1986 Nov [cited 2018 Oct 4];69(5):355-62. Available from: http://www.ncbi.nlm.nih.gov/pubmed/3792471

18. Alemu G, Mama M. Intestinal helminth coinfection and associated factors among tuberculosis patients in Arba Minch, Ethiopia. BMC Infect Dis [Internet]. BioMed Central; 2017 [cited 2018 Oct 10];17(1):68. Available from: http://www.ncbi. nlm.nih.gov/pubmed/28086814 doi: 10.1186/ s12879-017-2195-1

19. Debalke S, Worku A, Jahur N, et al. Soil transmitted helminths and associated factors among schoolchildren in government and private primary school in Jimma Town, Southwest Ethiopia. Ethiop J Health Sci [Internet]. College of Public Health and Medical Sciences of Jimma University; 2013 Nov [cited 2018 Oct 4];23(3):237-44. Available from: http://www.ncbi.nlm.nih.gov/ pubmed/24307823 doi: 10.4314/ejhs.v23i3.6

20. Trang DT, Mølbak K, Cam PD, et al. Helminth infections among people using wastewater and human excreta in peri-urban agriculture and aquaculture in Hanoi, Vietnam. Trop Med Int Heal [Internet]. 2007;12(SUPPL. 2):82-90. Available from: https://onlinelibrary.wiley.com/ doi/full/10.1111/j.1365-3156.2007.01945.x doi: 10.1111/j.1365-3156.2007.01945.x

21. Salgame P, Yap GS, Gause WC. Effect of helminth-induced immunity on infections with microbial pathogens. Nat Immunol [Internet]. 2013 Nov [cited 2018 Oct 10];14(11):1118-26. Available from: http://www.ncbi.nlm.nih.gov/ pubmed/24145791 doi: 10.1038/ni.273 